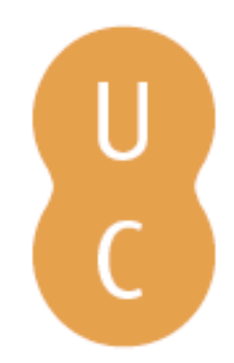

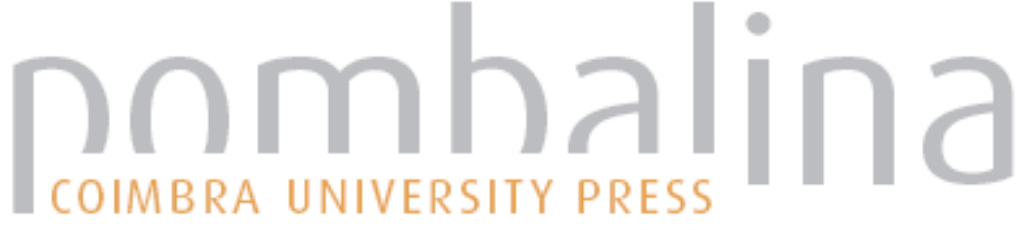

\section{Circulation weather types and their influence on the fire regime in Portugal}

Autor(es): $\quad$ DaCamara, Carlos C.; Trigo, Ricardo M.

Publicado por: Imprensa da Universidade de Coimbra

URL

persistente: URI:http://hdl.handle.net/10316.2/44557

DOI: $\quad$ DOI:https://doi.org/10.14195/978-989-26-16-506_40

Accessed : $\quad$ 26-Apr-2023 15:20:31

A navegação consulta e descarregamento dos títulos inseridos nas Bibliotecas Digitais UC Digitalis, UC Pombalina e UC Impactum, pressupõem a aceitação plena e sem reservas dos Termos e Condições de Uso destas Bibliotecas Digitais, disponíveis em https://digitalis.uc.pt/pt-pt/termos.

Conforme exposto nos referidos Termos e Condições de Uso, o descarregamento de títulos de acesso restrito requer uma licença válida de autorização devendo o utilizador aceder ao(s) documento(s) a partir de um endereço de IP da instituição detentora da supramencionada licença.

Ao utilizador é apenas permitido o descarregamento para uso pessoal, pelo que o emprego do(s) título(s) descarregado(s) para outro fim, designadamente comercial, carece de autorização do respetivo autor ou editor da obra.

Na medida em que todas as obras da UC Digitalis se encontram protegidas pelo Código do Direito de Autor e Direitos Conexos e demais legislação aplicável, toda a cópia, parcial ou total, deste documento, nos casos em que é legalmente admitida, deverá conter ou fazer-se acompanhar por este aviso.

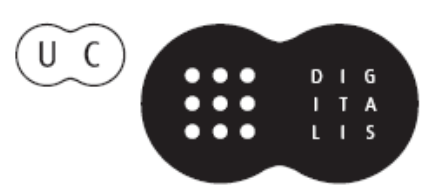




\section{ADVANCES IN}

\section{FOREST FIRE RESEARCH}

\section{8}

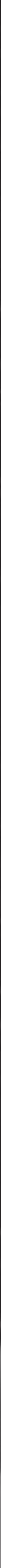




\title{
Circulation weather types and their influence on the fire regime in Portugal
}

\author{
Carlos C. DaCamara*; Ricardo M. Trigo \\ Instituto Dom Luiz,(IDL), Faculdade de Ciências, Universidade de Lisboa, Lisbon, 1749-016, \\ Portugal, \{cdcamara@fc.ul.pt*,rmrigo@fc.ul.pt\}
}

\begin{abstract}
The fire regime in Portugal presents a marked annual cycle that is here characterized based on values of radiant energy released by wildfires as detected by Meteosat geostationary satellites. The role played by meteorological conditions in the fire regime is then analyzed from the point of view of synoptic climatology. For this purpose, we use $10 \mathrm{Lamb}$ circulation weather types (CWTs) that are grouped into 8 directional types, associated to the cardinal and intercardinal directions of the geostrophic flow, and 2 rotational types (cyclonic and anticyclonic), associated to the positive and negative signs of geostrophic vorticity.

The study covers the 14-year period from January 2004 to December 2017. The monthly distribution of total fire radiative energy presents large values during the fire season (defined by the months spanning from July to October), with a very strong peak located in August. A secondary peak, located in March, is also clearly visible. The number of fire days (i.e. days where there is a recorded release of fire energy in Portugal) during the fire season represents $56 \%$ of the total number of fire days but contributes to $92 \%$ of the total Fire Radiative Energy (FRE) released by wildfires.

When analyzing the fire season from the point of view of CWTs, results indicate that $61 \%$ of the FRE released in 2004-2017 is observed in days characterized by directional types NE and E that just occur in $28 \%$ of the fire days. The contrast is especially marked when restricting to the E type that occurs only in $8 \%$ of the fire days but contributes to $25 \%$ of the energy released. In turn, the dominant anticyclonic type, that occurs in $31 \%$ of the fire days, contributes to just $15 \%$ of the total FRE. The role played by the different CWTs is also noticeable in March, where fire days represent 36\% of all March days and contribute to $2 \%$ of the total energy released in 2004-2017. Types E and SE that occur only in 14\% of the fire days are responsible for $71 \%$ of the total FRE in March and more than half (37\%) of this amount is released in days of type SE that are observed only in $5 \%$ of the days.

The importance of the contribution of NE and E types for the fire regime in Portugal is enhanced when restricting to the days with extreme release of energy. The distribution of daily FRE is long tailed with 5\% of the extreme fire days (113 days) accounting for 69\% of the total FRE. A very large proportion (96\%) of these extreme days took place in the fire season, namely in August (62\%), July (20\%), September (9\%) and October $(6 \%)$. Almost two thirds (66\%) of the released energy by extreme events are associated to directional types $\mathrm{NE}(36 \%)$ and $\mathrm{E}(30 \%)$.
\end{abstract}

Keywords: fire regime, fire radiative energy, circulation weather types, fire meteorology

\section{Introduction}

The tragic dimension of the fire events of 2017 in Portugal, both in terms of loss of human lives and of economic and social harm, has put at stake long-term established policies of fire management and has uncovered the vulnerabilities at the structural and operational levels of the current system of fire prevention and combat. Today, more than ever, there is a crucial need for reliable meteorological information, namely on the impact of prevailing weather conditions on fire behavior that will assist decision makers in taking preventive measures (e.g. prescribed fires) and in allocating resources to be employed.

The establishment of an optimal system of fire prevention and combat requires, in particular, having a thorough understanding of the factors playing a major role in extreme fire seasons characterized by 
an anomalously high or low number of ignitions, by very large or small amounts of burned area or by catastrophic or negligible impacts on the landscape or socio-economic activities. In this work, the fire regime in Portugal will be analyzed using daily values of fire radiative energy (FRE) released by wildfires as detected from radiometers on-board of geostationary satellite platforms. FRE is a physical property that has the advantage of being related to the amount of fuel burned and has been used as a proxy of fire line intensity in fire management and firefighting studies (Johnston et al., 2017).

Meteorological and climatic factors play a crucial role in fire behavior in Portugal. For instance, more than $2 / 3$ of the inter-annual variability of burned area is explained by meteorological factors namely i) the temperature and precipitation regimes of the spring preceding the fire season and ii) the occurrence during the fire season of circulation patterns of short-duration that induce extremely hot and dry spells over western Iberia (Pereira et al., 2005; Pereira et al., 2013).

The aim of this work is to assess the role played by meteorological conditions in the fire regime in Portugal. For this purpose, we adopt the point of view of synoptic climatology and use circulation weather types (CWTs) originally developed for the British Isles and later adapted to Portugal (Trigo and DaCamara, 2000). The versatility of this tool has already proven successful in a wide range of studies in Portugal and the Iberian Peninsula that include the precipitation regime (Trigo and DaCamara, 2000) and lightning activity (Ramos et al., 2011) in Portugal, and, for Iberia, the spatial variability of precipitation (Ramos et al., 2014) and drought (Russo et al., 2015), wildfire activity (Trigo et al., 2013) and upwelling activity along the western coast of Iberia (Ramos et al., 2013). Here, the impact of weather on wildfire activity is assessed by systematically comparing the contributions of the different CWTs to the FRE released by wildfires, special attention being devoted to CWTs associated to extreme fire days, defined as the top $5 \%$ of days with largest released FRE.

\section{Data and methods}

Daily values of radiative energy released by wildfires in Portugal covering the 14-year period 20042017 were extracted from the Fire Radiative Power (FRP) product (Wooster et al., 2015) of EUMETSAT Satellite Application Facility on Land Surface Analysis (LSA SAF) that is based on information provided by the SEVIRI radiometer on-board Meteosat Second Generation (MSG) series of geostationary satellites operated by EUMETSAT (Trigo et al. 2011).

Classification of daily weather is based on Lamb circulation weather types (CWTs) as derived from sea level pressure fields covering the same period. Daily values of surface pressure were extracted from the ERA Interim reanalysis dataset (Dee et al., 2011) generated by the European Centre for Medium-Range Weather Forecasts (ECMWF).

As for the Lamb CWTs developed for the UK, the CWTs for Portugal are grouped into 8 directional (NE, E, SE, S, SW, W, NW and N) associated to the cardinal and intercardinal directions of the geostrophic flow, and 2 rotational types (cyclonic and anticyclonic) according to the two signs of geostrophic vorticity (Trigo and DaCamara, 2000).

\section{Results}

The monthly distribution of fire days (i.e. days where there is a recorded release of FRE by wildfires in Portugal) presents large values (above 200 fire days) during the period from July to October, hereafter referred to as the fire season (Figure 1, upper panel); the peak in August is closely followed by July. There is a secondary peak, located in March, with the number of fire days slightly above 150 and the remaining months present values below this threshold. 

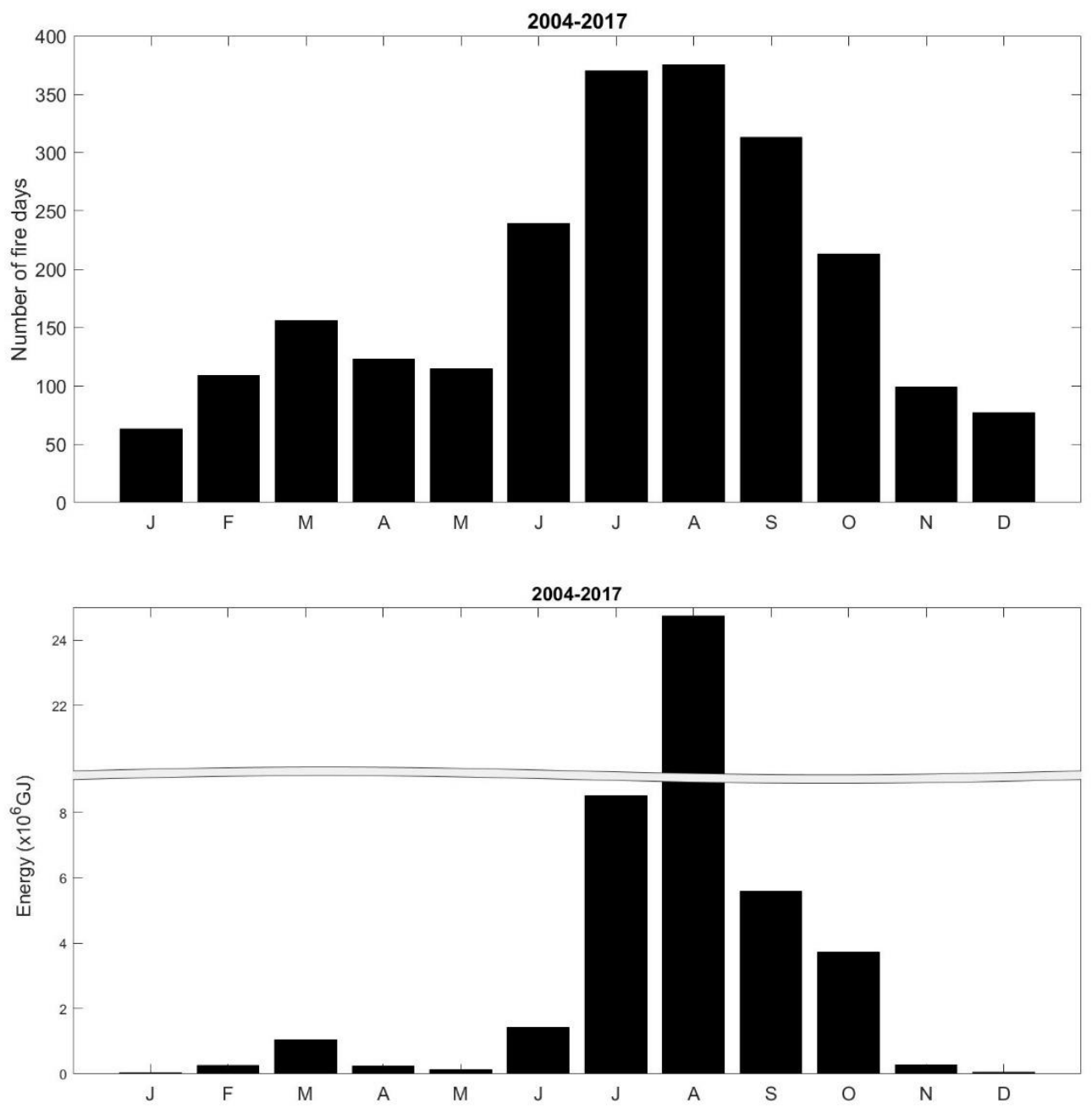

Figure 1 - Monthly distribution of fire days (upper panel) and of associated total fire radiative energy (lower panel) during the period 2004-2017.

The monthly distribution of total FRE (Figure 1, lower panel) is consistent with that of fire days with the higher values occurring during the fire season with a peak in August, and with a secondary peak in March; however, the peak in August of FRE is conspicuously high.

It is worth noting that the annual cycle of FRE is much more pronounced than that of fire days. For instance, the fire season contains $56 \%$ of all fire days in 2004-2017 but contributes to $92 \%$ of the total FRE $\left(4.6 \times 10^{7} \mathrm{GJ}\right)$, with August representing $17 \%$ of all fire days (30\% days of the fire season) and contributing to $54 \%$ of total FRE (and 58\% of FRE in the fire season).

The role played by meteorological conditions in the fire regime was analysed by comparing the relative frequency of occurrences of each $\mathrm{CWT}$ in each month with the relative contribution of that CWT to the total FRE of the considered month (Figure 2).

From June to October the number of fire days in each month represents always more than $49 \%$ of the total number of days of that month, with July and August having each more than $85 \%$ of fire days. Fire days in March represent 36\% of days and, in the remaining months, they represent less than $30 \%$ of the days of the respective month (a minimum of $15 \%$ being observed in January).

The anticyclonic (A) type is the most frequent CWT in fire days of all months except August when the NE type presents a slightly higher frequency of occurrence; however, the relative contribution of A to FRE is always lower that the relative frequency indicating that fire events associated to the A type tend to release lower values of radiative energy. The same happens with CWTs characterized by winds 
with a westerly component ( $\mathrm{SW}, \mathrm{W}$ and $\mathrm{NW}$ ) as well as with the $\mathrm{N}$ type that is more frequent from May to August and, together with the A type is associated to days with a moderate release of FRE.

An opposite behavior is observed with CWTs characterized by winds with an easterly component (NE, E and SE) where the relative contributions to the monthly total of FRE are almost always larger than the respective relative frequency of occurrence, namely the E type in all months, the NE type from December to January and from May to August, and the SE type from December to June. The C type presents larger contributions to FRE than the relative frequency of occurrences in March, June and July and the same happens in April, June and September.

When analysing the whole fire season (Figure 3), results indicate that $61 \%$ of FRE released in the fire season is observed in days characterized by directional types $\mathrm{NE}$ and $\mathrm{E}$ that occur in less than half that fraction (29\%) of the days. When considering type E alone, one fourth $(25 \%)$ of the energy released is associated to less than three times that fraction (8\%) of days of type E. On the other hand, the dominant A type occurs in $31 \%$ of the days but contributes to only $15 \%$ of the total FRE. Directional type $\mathrm{N}$ that ranks third (after NE) occurs in $14 \%$ of the days and account for $11 \%$ of the released energy. Directional types with a westerly component (SW, W and NW) representing $16 \%$ of the days contribute to $6 \%$ of FRE.

March, being the month with secondary peaks in fire days and released energy is also worth being analyzed in detail. As shown in Figure 1, the total FRE released in March is $1 \times 10^{6}$ GJ, representing $2 \%$ of the total energy released in 2004-2017. Types E and SE that occur only in $14 \%$ of the days are responsible for $71 \%$ of the total FRE more than half (37\%) of this amount being released in days of type SE that are observed only in about $5 \%$ of the days.
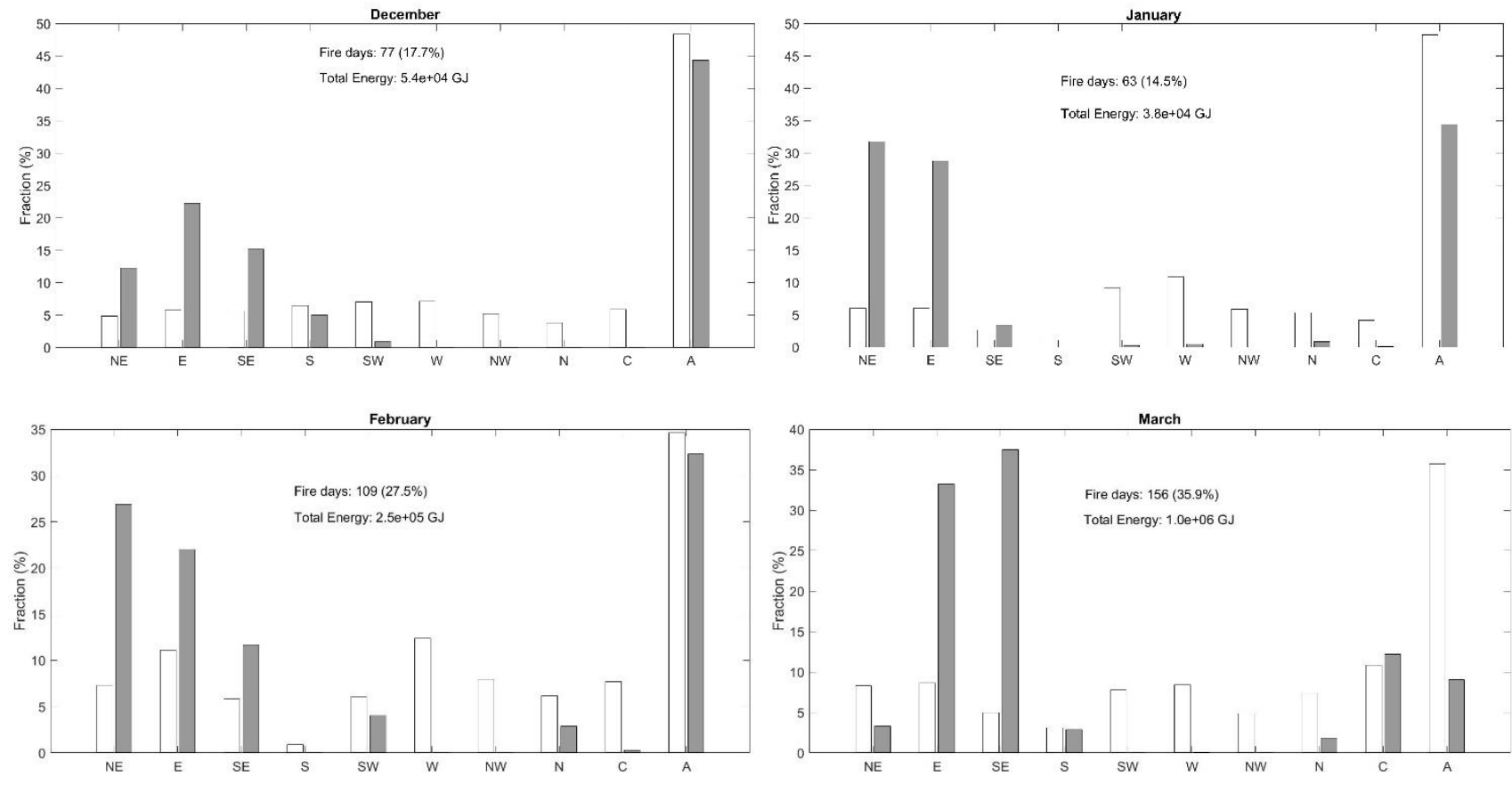

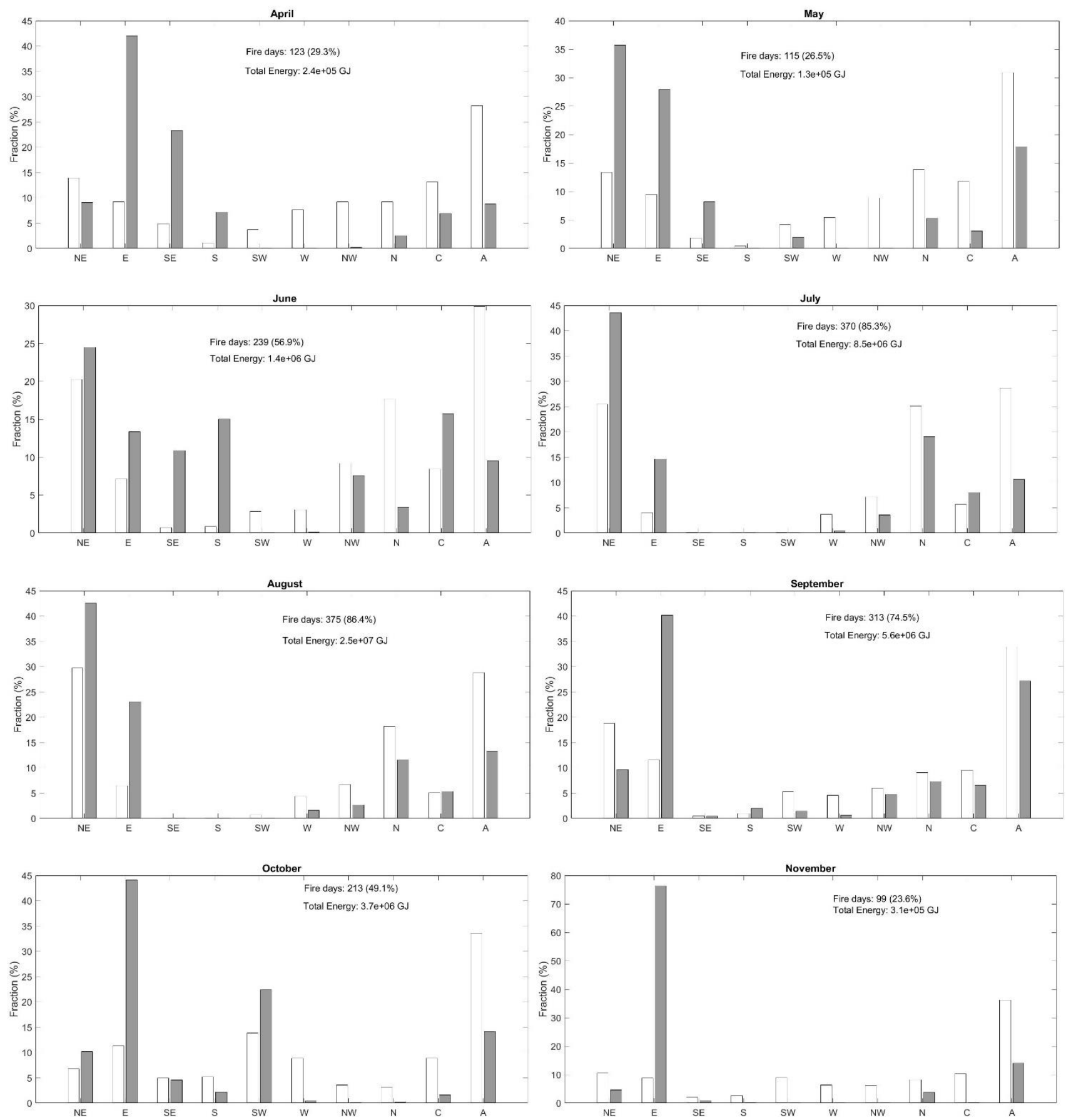

Figure 2 - Monthly analysis of contributions of CWTs to FRE during the period 2004-2017. For each CWT, the white column represents the fraction of days of that type during the considered period and the dark grey column represents the corresponding associated fraction of $\mathrm{FRE}$ 


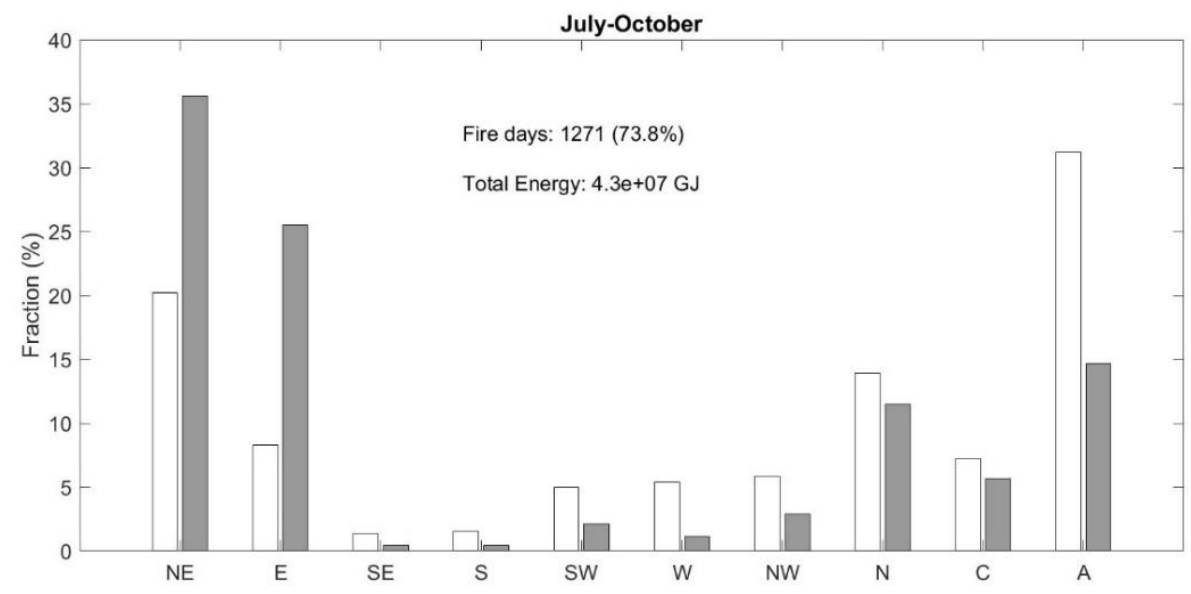

Figure 3 - As in Figure 2 but for the fire season (July to October).

It is a well-known fact that a relatively small number of wildfires are responsible for a very high proportion of the total energy released (Pinto et al., 2018). The distribution of daily FRE is therefore long tailed and this is put into evidence by means of the extreme proportion function (Figure 4) that is defined as the proportion of FRE attributable to the largest percentage of the fires (Strauss et al., 1989). The long-tailed character of the distribution of daily FRE translates into the very sharp increase of the extreme proportion curve for values of fraction of fire days within the range from 0 to about 0.1 . For instance, it may be noted that $1 \%$ of fire days (23 days) account for $31 \%$ of the total FRE, $2 \%$ of fire days (45 days) account for $45 \%$ of the total FRE and 5\% of fire days (113 days) account for 69\% of the total FRE.

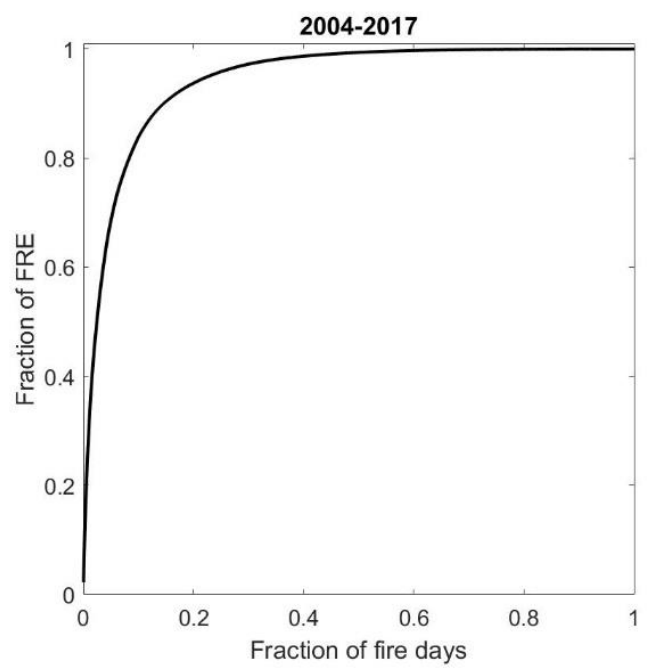

Figure 4 - The extreme proportion function for daily FRE released by wildfires during 2004-2017.

These results strongly suggest analysing in further detail the role played by meteorological conditions in days characterized by extremely high amounts of released energy by wildfires, e.g. restricting the sample to the top 5\% of fire days with the largest values of FRE. The clear majority (96\%) of these extreme fire days takes place during the fire season, with 62\% occurring in August, followed by July (19\%), September (9\%) and October (6\%), and the remaining $4 \%$ of events are evenly distributed in March and June. Concerning the relative frequency of occurrence and the relative contribution to the FRE (Figure 5), it is worth emphasizing that two thirds (66\%) of the released energy in extreme days are associated to directional types NE (36\%) and E (30\%) with a frequency of 
occurrence of $62 \%$. These results put into evidence the role of $\mathrm{NE}$ and $\mathrm{E}$ types in days of extreme fire events.

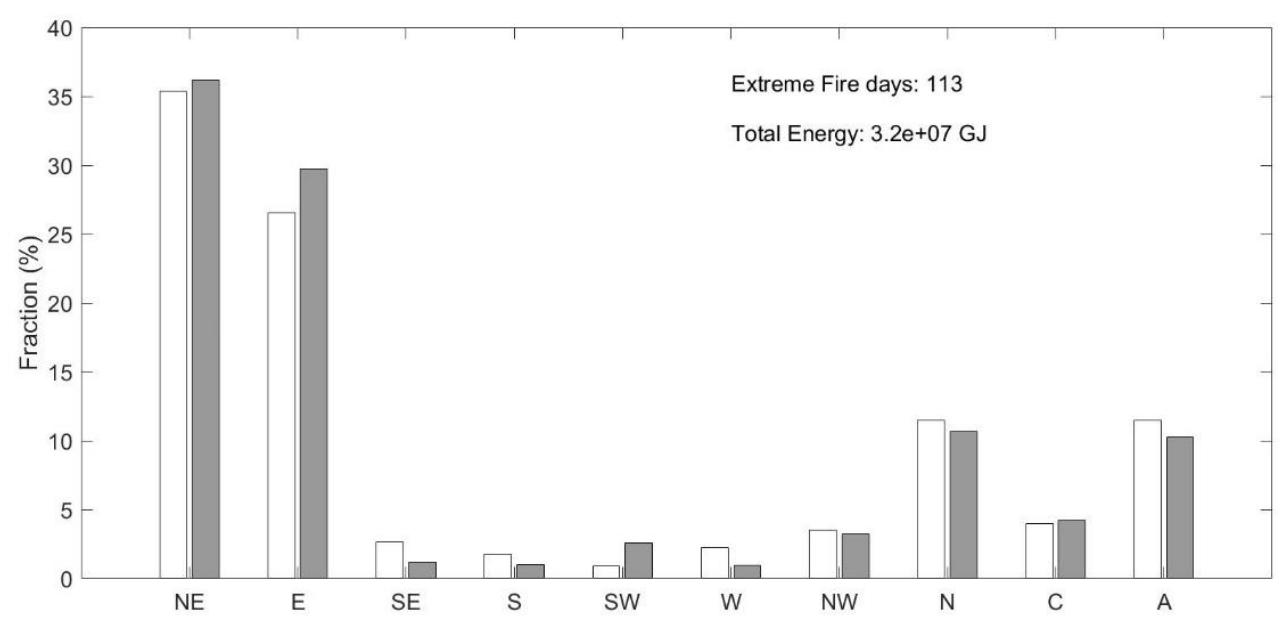

Figure 5 - As in Figure 2 but for the extreme fire days (top 5\%).

\section{Concluding remarks}

The fire regime in Portugal presents a marked annual cycle both in terms of number of fire days and in the amount of energy released by wildfires. The role of meteorological conditions in modulating the fire regime was assessed using the approach of synoptic climatology where daily weather conditions are stratified into eight directional weather types (associated to the prevailing wind direction) and two rotational types (associated to the sign of vorticity, i.e. cyclonic $\mathrm{C}$ or anticyclonic A).

The analysis encompassed the period 2004-2017 and results obtained showed that despite being the most frequently occurring Circulation Weather Type (CWT) in all months but August (where it ranks very close to first), the anticyclonic (A) type always contributes in a lower proportion to the Fire Radiative Energy (FRE) released by fires. On the contrary, the relative contribution of type E to FRE is larger than the frequency of occurrence in all months and the same happens with the remaining two CWTs characterized by an easterly wind component, namely the NE type from December to January and from May to August, and the SE type from December to June. The role played by CWTs characterized by east wind is further emphasized when restricting to the top 5\% of days with largest release of FRE; in this case, two thirds of the released energy are associated to directional types NE and $\mathrm{E}$.

These results open an interesting perspective for future studies involving seasonal forecasts and model simulations of present climate and future scenarios where approaches based on weather types have proven to be a useful tool for model validation (Ramos et al., 2015). This is especially important given that according to different scenarios of future climate in the Mediterranean, extreme fire events are likely to become more frequent (Flannigan et al., 2013; Pereira et al., 2013; Sousa et al., 2015).

\section{Acknowledgments}

Research performed is in the framework of Brazilian Fire-Land-Atmosphere System (BrFLAS) Project financed by the Portuguese and Brazilian science foundations, FCT and FAPESP (project references FAPESP/1389/2014 and 2014/20042-2) and of EUMETSAT Satellite Application Facility for Land Surface Analysis (LSA SAF). 


\section{References}

Dee DP, Uppala SM, Simmons AJ, Berrisford P, Poli P, Kobayashi S, Andrae U, Balmaseda MA, Balsamo G, Bauer P, Bechtold P, Beljaars ACM, van de Berg L, Bidlot J, Bormann N, Delson C, Dragani R, Fuentes M, Gee AJ, Haimberger L, Healy SB, Hersbach H, Hólm EV, Isaksen L, Kallberg P, Köhler M, Matricardi M, McNally AP, Monge-Sanz BM, Morcrette J-J, Park B-K, Peubey C, de Rosnay P, Tavolato C, Thépaut J-N, Vitart F (2011) The ERA-Interim reanalysis: Configuration and performance of the data assimilation system, Quarterly Journal of the Royal Meteorological Society, 137, 553-597. doi: 10.1002/qj.828

Flannigan M, Cantin AS, de Groot WJ, Wotton M, Newbery A, Gowman LM (2013) Global wildland fire season severity in the 21st century. Forest Ecology and Management 294, 54-61. https://doi.org/10.1016/j.foreco.2012.10.022.

Johnston JM. Wooster MJ, Paugam R, Wang X, Lynham TJ, Johnston L M (2017) Direct estimation of Byram's fire intensity from infrared remote sensing imagery, International Journal of Wildland Fire, 26, 668-684. doi:10.1071/WF16178

Pereira MG, Calado TJ, DaCamara CC, Calheiros T (2013) Effects of regional climate change on rural fires in Portugal. Climate Research 57, 187-200. doi: 10.3354/cr01176

Pereira MG, Trigo RM, DaCamara CC, Pereira J.M.C., Leite SM (2005). Synoptic patterns associated with large summer forest fires in Portugal, Agricultural and Forest Meteorology, 129, 11-25. doi:10.1016/j.agrformet.2004.12.007

Pinto MM, DaCamara CC, Trigo IF, Trigo RM, Turkman KF (2018) Fire danger rating over Mediterranean Europe based on fire radiative power derived from Meteosat. Natural Hazards Earth System Science 18, 515-529, https://doi.org/10.5194/nhess-18-515-2018.

Ramos AM, Cordeiro Pires A, Sousa PM, Trigo RM (2013) The use of circulation weather types to predict upwelling activity along the Western Iberian Peninsula coast. Continental Shelf Research 69, 38-51. doi: 10.1016/j.csr.2013.08.019

Ramos AM, Barriopedro D, Dutra E (2015) Circulation weather types as a tool in atmospheric, climate, and environmental research. Frontiers of Environmental Science 3:44. doi: 10.3389/fenvs.2015.00044

Ramos AM, Cortesi N, Trigo RM (2014) Circulation weather types and spatial variability of daily precipitation in the Iberian Peninsula. Frontiers of Earth Science 2:25. doi: 10.3389/feart.2014.00025

Ramos AM, Ramos R, Sousa P, Trigo RM, Janeira M, Prior V (2011) Cloud to ground lightning activity over Portugal and its association with circulation weather types. Atmospheric Research 101, 84-101. doi: 10.1016/j.atmosres.2011.01.014

Russo AC, Gouveia CM, Trigo RM, Liberato MLR, DaCamara CC (2015) The influence of circulation weather patterns at different spatial scales on drought variability in the Iberian Peninsula. Frontiers in Environmental Science 3:1. doi: 10.3389/fenvs.2015.00001

Sousa PM, Trigo RM, Pereira MG, Bedia J, Gutiérrez JM (2015) Different approaches to model future burnt area in the Iberian Peninsula. Agricultural and Forest Meteorology 202, 11-25. doi: http://dx.doi.org/10.1016/j.agrformet.2014.11.018

Strauss D, Bednar L, Mees R (1989) Do one percent of forest fires cause ninety nine percent of the damage? Forest Science 35, 319-328.

Trigo IF, DaCamara CC, Viterbo P, Roujean J -L, Olesen F, Barroso C, Camacho de Coca F , Freitas SC , García-Haro J, Geiger B , Gellens-Meulenberghs F, Meliá J, Pessanha L, Siljamo N (2011) The Satellite Application Facility for Land Surface Analysis, International Journal of Remote Sensing, 32, 2725-2744. doi:10.1080/01431161003743199 
Trigo RM, DaCamara CC (2000) Circulation weather types and their Influence on the precipitation regime in Portugal. International Journal of Climatology 20, 1559-1581. doi: 10.1002/10970088(20001115)20:13<1559::AID-JOC555>3.0.CO;2-5

Trigo RM, Sousa P, Pereira M, Rasilla D, Gouveia CM (2013) Modelling wildfire activity in Iberia with different Atmospheric Circulation Weather Types, International Journal of Climatology. doi: 10.1002/joc.3749

Wooster MJ, Roberts G, Freeborn PH, Xu W, Govaerts Y, Beeby R, He J, Lattanzio A, Fisher D, Mullen R (2015) LSA SAF Meteosat FRP products - Part 1: Algorithms, product contents, and analysis. Atmos. Chem. Phys. 15, 13217-13239. https://doi.org/10.5194/acp-15-13217-2015. 